\title{
DIFFERENCES IN FATTY ACID COMPOSITION OF MEAT BETWEEN NAKED NECK AND TWO COMERCIAL BROILER CHICKEN BREEDS
}

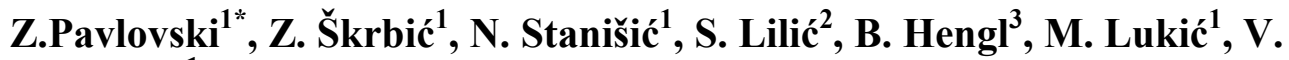 Petričević $^{1}$}

\author{
${ }^{1}$ Institute for Animal Husbandry, Autoput 16, 11080, Belgrade-Zemun, Republic of Serbia \\ ${ }^{2}$ Institute of Meat Hygiene and Technology, Kaćanskog 13, 11000 Belgrade, Republic of Serbia \\ ${ }^{3}$ Croatian Food Agency, I. Gundulića 36b, 31000 Osijek, Republic Croatia \\ *Corresponding author: zlaticapav@yahoo.com \\ Original scientific paper
}

\begin{abstract}
Chicken meat from intensive broiler production have different quality compared with meat from native chicken breeds and chicken from a free range production system. The aim of the present study was to evaluate differences in fatty acids content of meat of Naked Neck chickens rared in free range system and two commercial broiler breeds (Cobb 308 and Hybro G+) reared in conventional production system. The trial involved 100 chickens per group. Fattening period lasted 42 days for convencional system and 84 days for free range system. Breast meat of Naked Neck chicken had statisticaly more 16:0 content compared with Cobb $308(\mathrm{p} \leq 0.05)$, where in thigh meat the highest content of 16:0 was determined in Hybro $\mathrm{G}+$ breed. Differences for fatty acids composition of breast meat between breeds were also established for 14:0, 17:0, 18:0, 16:1, 18:1, 18:2, 20:2, 22:1 and 22:5 fatty acid. The Naked Neck group showed the highest $(p \leq 0.05)$ percentage of SFA and the Cobb 308 showed the lowest in breast meat. Thigh SFA were also significantly different $(\mathrm{p} \leq 0.05)$ between breeds, where Naked Neck chickens had the lowest and Hybro G+ the highest values. Breast MUFA were higher in Hybro G+ than in Naked Neck or Cobb 308 chickens, and thigh MUFA content had opposite trend and it was the lowest in Hybro G+ chicken. In conclusion, free ranged Naked Neck chickens have been shown to have significant different fatty acid composition compared with broiler chikens reared in conventional system.
\end{abstract}

Key words: Naked Neck, broiler chicken, free range, fatty acid, meat

\section{Introduction}

Intensive broiler production, as an integral part of industrial poultry production, began its development in the United States after World War II and in 
Serbia in around 1960s and it allowed the quantitative satisfaction markets with relatively cheap chicken meat throughout the year. The relatively poor quality of chicken meat from intensive broiler production (watery meat, insufficiently taste and aroma, a large percentage of fat under skin and in the abdominal cavity, weak and brittle bones, etc..) and development of consumer awareness about animal welfare and food safety, have led to the emergence of the perception that broilers meat is not healthy and natural (Škrbić et al., 2010).

Concequently, the number of the native chickens has been increasing for the past 20 years to satisfy the customer demands for more intense flavor and firmness of their meat. Today, a greater proportion of consumers in Europe and the United States are interested in broiler specialty products derived from free-range production systems (Ponte et al., 2008).

In our country, only few authors has investigated rering of native chickens and meat quality in free range system (Bogosavljević-Boškovićet al., 2003; Milošević et al.,2003; Milošević et al., 2005; Pavlovski et al.,2009a; Pavlovski et al.,2009b;).

Although numerous studies on breeding selection, methods of raising, dietary and growth performance and body composition of different chicken breeds have been widely conducted, little is know about fatty acids composition of native chicken breeds (for example Naked Neck breed). Regarding this, the aim of the present work was to evaluate differences in fatty acids content of meat of Naked Neck chickens rared in free range system compared with two commercial broiler breeds (Cobb 308 and Hybro $\mathrm{G}^{+}$) reared in conventional system.

\section{Materials and methods}

Naked Neck and commercial hens were reared in the Experimental Centre of the Institute for animal husbandry (Belgrade, Serbia) in two systems: conventional (Cobb 500 and Hybro $\mathrm{G}^{+}$) and free range (Nacked Neck). The trial involved 100 chickens per group. Fattening period lasted 42 days for convencional system and 84 for free range system. The free range system applied the technology of production of chicken meat that was developed in the Institute for animal husbandry (Škrbić et al., 2010). Composition of animal food used for fattening is presented in Tables 1 and 2. 
Table 1. Composition of feed used in convencional system

\begin{tabular}{|l|c|c|c|c|}
\hline$\%$ & $\begin{array}{c}\text { Prestarter } \\
1-7 \text { day }\end{array}$ & $\begin{array}{c}\text { Starter } \\
7-14 \text { day }\end{array}$ & $\begin{array}{c}\text { Grower } \\
14-35 \text { day }\end{array}$ & $\begin{array}{c}\text { Finisher } \\
35-42 \text { day }\end{array}$ \\
\hline Corn & 54.45 & 50.79 & 53.84 & 54.20 \\
\hline Wheat meal & 2.00 & 2.50 & 1.00 & 4.00 \\
\hline Soybean meal & 25.00 & 25.00 & 23.50 & 23.00 \\
\hline Sunflower meal & 5.00 & 5.00 & 6.00 & 5.00 \\
\hline Yeast & 3.00 & 3.00 & 3.00 & 3.00 \\
\hline Fishmeal & 5.00 & 4.00 & 3.00 & - \\
\hline Alfalfa (dehydrated) & - & 2.00 & 2.00 & 2.00 \\
\hline Soybean oil & 3.00 & 5.00 & 4.50 & 5.50 \\
\hline Dicalcium phosphate & 1.00 & 1.20 & 1.30 & 1.10 \\
\hline Chalk & - & - & 0.20 & 0.40 \\
\hline Salt & 0.20 & 0.20 & 0.30 & 0.30 \\
\hline Lysine & 0.10 & 0.06 & 0.11 & 0.25 \\
\hline Methionine & 0.25 & 0.25 & 0.25 & 0.25 \\
\hline Premix & 1.00 & 1.00 & 1.00 & 1.00 \\
\hline CHEMICAL COMPOSITION: & & & & \\
\hline Moisture & 11.03 & 10.72 & 10.79 & 20.85 \\
\hline Ash & 5.61 & 5.79 & 5.96 & 5.44 \\
\hline Protein & 22.73 & 22.23 & 21.34 & 19.48 \\
\hline Fat & 5.93 & 7.76 & 7.28 & 8.16 \\
\hline Crude fiber & 3.94 & 4.37 & 4.51 & 4.37 \\
\hline Ca & 0.95 & 0.97 & 0.99 & 0.81 \\
\hline P & 0.86 & 0.85 & 0.85 & 0.71 \\
\hline ME, MJ/kg & 12.92 & 13.23 & 13.12 & 13.43 \\
\hline Lysine & 1.36 & 1.30 & 1.26 & 1.20 \\
\hline Methionine + cystine & 0.97 & 0.95 & 0.92 & 0.84 \\
\hline Tryptophan & 0.31 & 0.31 & 0.29 & 0.27 \\
\hline
\end{tabular}

Table 2. Composition of feed used in free range system

\begin{tabular}{|l|c|c|c|c|}
\hline$\%$ & $\begin{array}{c}\text { Starter } \\
1-14 \text { day }\end{array}$ & $\begin{array}{c}\text { Grower 1 } \\
14-28 \text { day }\end{array}$ & $\begin{array}{c}\text { Grower 2 } \\
28-42 \text { day }\end{array}$ & $\begin{array}{c}\text { Finisher } \\
\text { 42-84 day }\end{array}$ \\
\hline Corn & 54.7 & 64.0 & 71.0 & 77.0 \\
\hline Soybean meal & 37.0 & 29.0 & 23.4 & 18.5 \\
\hline Vegetable oil & 4.0 & 3.0 & 2.0 & 1.0 \\
\hline Chalk & 1.6 & 1.4 & 1.2 & 1.2 \\
\hline Dicalcium phosphate & 1.3 & 1.3 & 1.1 & 1.1 \\
\hline Salt & 0.4 & 0.3 & 0.3 & 0.2 \\
\hline Premix & 1.0 & 1.0 & 1.0 & 1.0 \\
\hline CHEMICAL COMPOSITION: & 3000 & 3050 & 3080 & 3100 \\
\hline Energy (kcal) & 21.0 & 18.2 & 16.5 & 15.0 \\
\hline Crude protein & 1.00 & 0.93 & 0.83 & 0.80 \\
\hline Ca & 0.70 & 0.65 & 0.60 & 0.55 \\
\hline P & \multicolumn{5}{|l}{} \\
\hline
\end{tabular}


At the end of trial all chickens were transferred to slaughterhouse and slaughter using standard techniques. Six hours before slaughtering animals were without feeding. After killing, the carcasses were cooled in ice cold water and then hung in a chilling chamber at $4^{0} \mathrm{C}$ for $24 \mathrm{~h}$ after chilling, from each carcass the breast and thigh were sampled for fatty acid analysis. Chemical analyses of meat samples (three repeats) were done at the Institute of hygiene and meat technology (Belgrade, Serbia).

Total lipids for fatty acids determination were extracted from meat by accelerated solvent extraction (ASE 200, Dionex, Sunnyvale, CA). Homogenate of sample mixed with diatomaceous earth, was extracted with a mixture of $\mathrm{n}$-hexane and iso-propanol $(60: 40 \mathrm{v} / \mathrm{v})$ in $33 \mathrm{ml}$ extraction cell at $100^{\circ} \mathrm{C}$ and nitrogen pressure of 10.3 MPa (Spirić et al., 2009). The extracts were collected and the solvent was removed under stream of nitrogen in Dionex Solvent Evaporator 500, at $50^{\circ} \mathrm{C}$ until dryness. Fat extract was further used for fatty acids and cholesterol determination meat. Fatty acid methyl esters (FAMEs) were prepared by transesterification by using trimethylsulfonium hydroxide, according to SRPS EN ISO 5509:2007 procedure. The GC instrument Shimadzu 2010 (Kyoto, Japan), used for FAMEs determination, was equipped with a split/splitless injector, fused silica cianopropyl HP-88 column (length $100 \mathrm{~m}$, i.d. $0.25 \mathrm{~mm}$, film thickness 0.20 $\mu \mathrm{m})$ and flame ionization detector (FID). The column temperature was programmed. Injector temperature was $250^{\circ} \mathrm{C}$ and detector temperature was $280^{\circ} \mathrm{C}$. The carrier gas was nitrogen at a flow rate of $1.33 \mathrm{ml} / \mathrm{min}$ and injector split ratio of 1:50.

The total proportion of saturated fatty acids (SFA) was the sum of the weight percentages of: myristic (14:0), pentadecanoic (15:0), palmitic (16:0), margaric (17:0) and stearic (18:0) acids. The total proportion of monounsaturated fatty acids (MUFA) was calculated by summing the weight percentages of: palmitoleic (16:1), oleic (18:1 cis-9) and gadoleic (20:1). Additionally, the total percentage of polyunsaturated fatty acids (PUFA) included: linoleic (18:2 n-6), $\gamma$ linolenic (18:3 n-6), $\alpha$-linolenic (18:3 n-3), eicosadienoic (20:2), dihomo- $\gamma$ linolenic (20:3n-6), docosapentaenoic (22:5n-3) and docosahexaenoic (22:6n-3) acid. The sum of all n- 6 fatty acids were calculated as sum of 18:2 n-6, 18:3n-6 and 20:3 n- 6 and the sum of all n-3 fatty acids as sum of 18:3n-3, 22:5n-3, and 22:6 n-3.

In order to determine the effect of breed on fatty acids composition, a single-factor analysis of variance was performed using Statistica 7 software (StatSoft, USA). T-test was performed for treatments comparison when differences were significant $(\mathrm{p} \leq 0.05)$. 


\section{Results and discussion}

The averages of fatty acids profiles of the breasts and thighs of investigated chicken breeds are presented in Tables 2 and 3, where various fatty acids were different in proportion among genotypes, but not all differences were similar in both muscles. Palmitic acid (16:0) was the major saturated fatty acid, fallowed by stearic acid (18:0), in both breast and thigh meat. However, breast meat of Naked Neck chicken had statisticaly more 16:0 content compared with Cobb 308 $(\mathrm{p} \leq 0.05)$, where in thigh meat the highest content of 16:0 was determined in Hybro $\mathrm{G}+$ breed. Differences for fatty acids composition of breast meat between breeds were also established for 14:0, 17:0, 18:0, 16:1, 18:1, 18:2, 20:2, 22:1 and 22:5 (Table 3).

Table 3. Fatty acid composition of breast meat of three chicken genotype

\begin{tabular}{|l|c|c|c|}
\hline Fatty acid (\%) & Naked Neck & Cobb 308 & Hybro G+ \\
\hline $14: 00$ & $0.60^{\mathrm{b}} \pm 0.05$ & $0.30^{\mathrm{a}} \pm 0.07$ & $0.87^{\mathrm{c}} \pm 0.12$ \\
\hline $15: 00$ & $0.08 \pm 0.01$ & $0.07 \pm 0.01$ & $0.07 \pm 0.01$ \\
\hline $16: 00$ & $23.97^{\mathrm{b}} \pm 1.33$ & $20.65^{\mathrm{a}} \pm 1.03$ & $23.61^{\mathrm{b}} \pm 0.93$ \\
\hline $16: 01$ & $1.76^{\mathrm{a}} \pm 0.09$ & $2.71^{\mathrm{b}} \pm 0.22$ & $6.05^{\mathrm{c}} \pm 0.23$ \\
\hline $17: 00$ & $0.18^{\mathrm{b}} \pm 0.01$ & $0.11^{\mathrm{a}} \pm 0.02$ & $0.12^{\mathrm{a}} \pm 0.02$ \\
\hline $18: 00$ & $7.62^{\mathrm{a}} \pm 0.42$ & $7.08^{\mathrm{ab}} \pm 0.20$ & $6.62^{\mathrm{b}} \pm 0.31$ \\
\hline $18: 1 \mathrm{c} \mathrm{n}-9$ & $39.97^{\mathrm{b}} \pm 1.35$ & $34.49^{\mathrm{a}} \pm 0.86$ & $36.25^{\mathrm{ab}} \pm 0.58$ \\
\hline $18: 2 \mathrm{n}-6$ & $22.20^{\mathrm{a}} \pm 0.59$ & $28.42^{\mathrm{b}} \pm 0.99$ & $21.36^{\mathrm{a}} \pm 0.87$ \\
\hline $18: 3 \mathrm{n}-3$ & $1.27 \pm 0.11$ & $1.61 \pm 0.18$ & $0.98 \pm 0.08$ \\
\hline $18: 3 \mathrm{n}-6$ & $0.17 \pm 0.02$ & $0.19 \pm 0.02$ & $0.15 \pm 0.02$ \\
\hline $20: 00$ & $0.07 \pm 0.01$ & $0.12 \pm 0.02$ & $0.10 \pm 0.02$ \\
\hline $20: 01$ & $0.36 \pm 0.06$ & $0.45 \pm 0.10$ & $0.41 \pm 0.09$ \\
\hline $20: 02$ & $0.14^{\mathrm{a}} \pm 0.03$ & $0.47^{\mathrm{b}} \pm 0.08$ & $0.42^{\mathrm{b}} \pm 0.06$ \\
\hline $20: 3 \mathrm{n}-6$ & $0.38 \pm 0.06$ & $0.40 \pm 0.07$ & $0.38 \pm 0.05$ \\
\hline $22: 1+\mathrm{C} 20: 4$ & $0.90^{\mathrm{a}} \pm 0.07$ & $2.04^{\mathrm{b}} \pm 0.06$ & $2.01^{\mathrm{b}} \pm 0.09$ \\
\hline $22: 5 \mathrm{n}-3$ & $0.09^{\mathrm{a}} \pm 0.01$ & $0.27^{\mathrm{b}} \pm 0.04$ & $0.13^{\mathrm{a}} \pm 0.02$ \\
\hline $22: 6 \mathrm{n}-3$ & $0.22 \pm 0.02$ & $0.20 \pm 0.02$ & $0.24 \pm 0.02$ \\
\hline
\end{tabular}

Results are expressed in mean \pm standard deviation.

$a, b, c-$ means within rows bearing different letters are significantly different at $p \leq 0.05$

Thighs meat of chickens, reared in free-range system, showed differences in fatty acids composition between breeds (Table 4). 
Table 4. Fatty acid composition of thighs meat of three chicken genotype

\begin{tabular}{|l|c|c|c|}
\hline Fatty acid (\%) & Naked Neck & Cobb 308 & Hybro G+ \\
\hline $14: 00$ & $0.44^{\mathrm{a}} \pm 0.08$ & $0.38^{\mathrm{a}} \pm 0.05$ & $1.44^{\mathrm{b}} \pm 0.05$ \\
\hline $15: 00$ & $0.06^{\mathrm{a}} \pm 0.01$ & $0.09^{\mathrm{b}} \pm 0.01$ & $0.10^{\mathrm{b}} \pm 0.02$ \\
\hline $16: 00$ & $19.71^{\mathrm{a}} \pm 1.28$ & $22.27^{\mathrm{b}} \pm 1.41$ & $26.97^{\mathrm{c}} \pm 1.31$ \\
\hline $16: 01$ & $2.44^{\mathrm{b}} \pm 0.19$ & $4.26^{\mathrm{c}} \pm 0.12$ & $1.80^{\mathrm{a}} \pm 0.14$ \\
\hline $17: 00$ & $0.13 \pm 0.02$ & $0.13 \pm 0.01$ & $0.11 \pm 0.01$ \\
\hline $18: 00$ & $6.50^{\mathrm{a}} \pm 0.39$ & $7.01^{\mathrm{ab}} \pm 0.13$ & $7.62^{\mathrm{b}} \pm 0.38$ \\
\hline $18: 1 \mathrm{c} \mathrm{n}-9$ & $41.24^{\mathrm{c}} \pm 1.37$ & $38.47^{\mathrm{b}} \pm 1.92$ & $29.41^{\mathrm{a}} \pm 1.16$ \\
\hline $18: 2 \mathrm{n}-6$ & $26.12^{\mathrm{b}} \pm 0.87$ & $23.74^{\mathrm{a}} \pm 0.79$ & $26.18^{\mathrm{b}} \pm 1.01$ \\
\hline $18: 3 \mathrm{n}-3$ & $1.34^{\mathrm{b}} \pm 0.14$ & $1.01^{\mathrm{a}} \pm 0.20$ & $3.96^{\mathrm{c}} \pm 0.33$ \\
\hline $18: 3 \mathrm{n}-6$ & $0.13 \pm 0.02$ & $0.11 \pm 0.01$ & $0.11 \pm 0.02$ \\
\hline $20: 00$ & $0.08 \pm 0.01$ & $0.10 \pm 0.01$ & $0.11 \pm 0.02$ \\
\hline $20: 01$ & $0.42^{2} \pm 0.04$ & $0.51 \pm 0.05$ & $0.45 \pm 0.05$ \\
\hline $20: 02$ & $0.15^{\mathrm{a}} \pm 0.02$ & $0.50^{\mathrm{b}} \pm 0.06$ & $0.48^{\mathrm{b}} \pm 0.07$ \\
\hline $20: 3 \mathrm{n}-6$ & $0.29^{\mathrm{a}} \pm 0.04$ & $0.49^{\mathrm{b}} \pm 0.05$ & $0.45^{\mathrm{b}} \pm 0.04$ \\
\hline $22: 1+\mathrm{C} 20: 4$ & $0.50^{\mathrm{a}} \pm 0.06$ & $0.66^{\mathrm{b}} \pm 0.10$ & $0.60^{\mathrm{b}} \pm 0.06$ \\
\hline $22: 5 \mathrm{n}-3$ & $<0.01$ & $<0.01$ & $<0.01$ \\
\hline $22: 6 \mathrm{n}-3$ & $<0.01$ & $<0.01$ & $<0.01$ \\
\hline $\mathrm{R}-3$ & & & \\
\hline
\end{tabular}

Results are expressed in mean \pm standard deviation.

$\mathrm{a}, \mathrm{b}, \mathrm{c}-$ means within rows bearing different letters are significantly different at $\mathrm{p} \leq 0.05$.

Castellini et al. (2002) have found that the the breast and thigh muscles of the organically reared animals had a higher fraction of saturated fatty acids (SFA) and lower one of monounsaturated (MUFA) compared to the control group. Authors also stated that this trend could be partly due to the different compositions of the ingested foods, caused by grass intake. Wattanachant et al. (2004) observed that although the chickens are fed with the same diet, there are some differences in their meat fatty acid content. Authors report that these were probably due to differences in feeding behaviour between breeds.

In this experiment, there were significantly differences between chicken breeds in fatty acid composition of breast and thigh (Fig. 1). As far as breast saturated fatty acids (SFA) are concerned (Fig. 1A), the Naked Neck group showed the highest $(\mathrm{p} \leq 0.05)$ percentage and the Cobb 308 showed the lowest, which is 
consistent with results reported by Wattanachant et al. (2004) for Thai indigenous breed. Thigh SFA (Fig. 1B) were also significantly different $(\mathrm{p} \leq 0.05)$ between breeds, where Naked Neck chickens had the lowest and Hybro $\mathrm{G}^{+}$the highest values.

There were no differences in MUFA level between indigenous and broiler breeds in experiment of Wattanachant et al. (2004). In this trial, total monounsaturated fatty acids showed variations among genotypes (Fig. 1). Breast MUFA (Fig. 1A), were higher in Hybro G+ than in Naked Neck or Cobb 308 chickens. Thigh MUFA content (Fig. 1B) had opposite trend and it was the lowest in Hybro G+ chicken. The MUFA content of all chickens in this study were lower than those reported by Castellini et al. (2002) for organically reared Ross male chickens, 56 days old. This could be due to the differences of lipids in the diets of the birds.

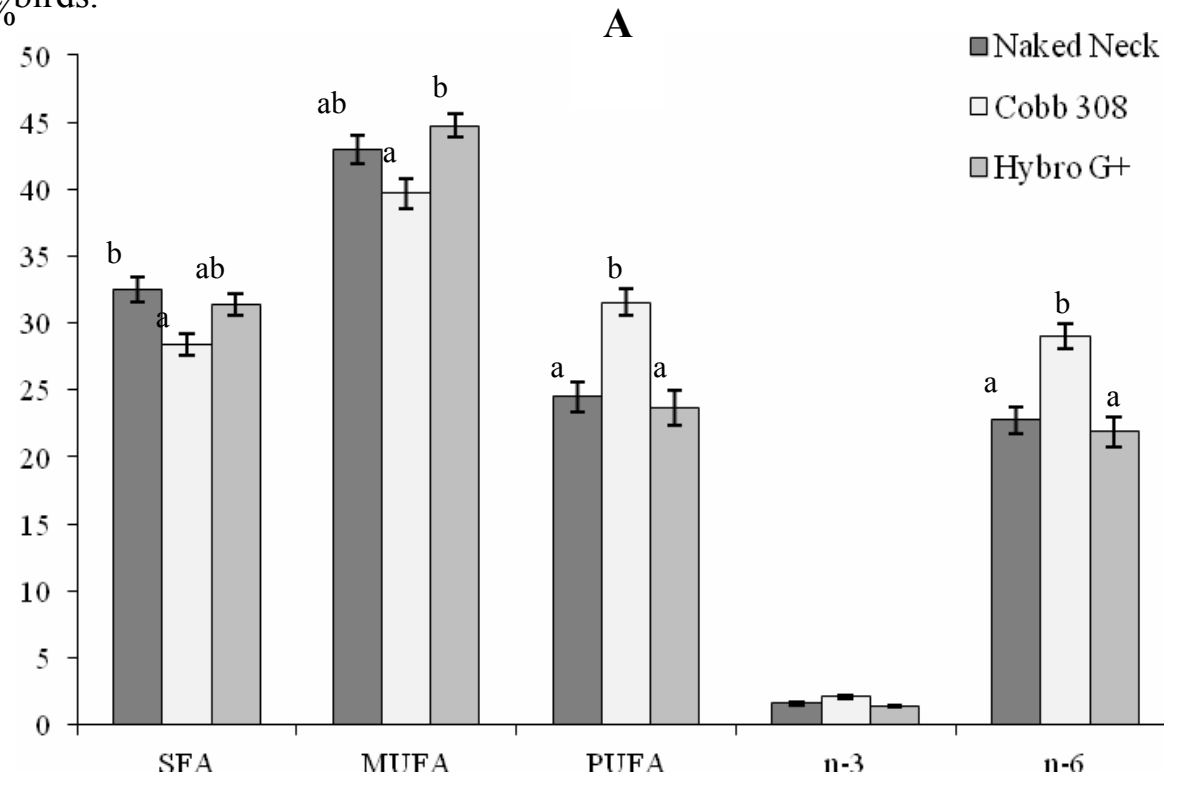

Total fatty acid 


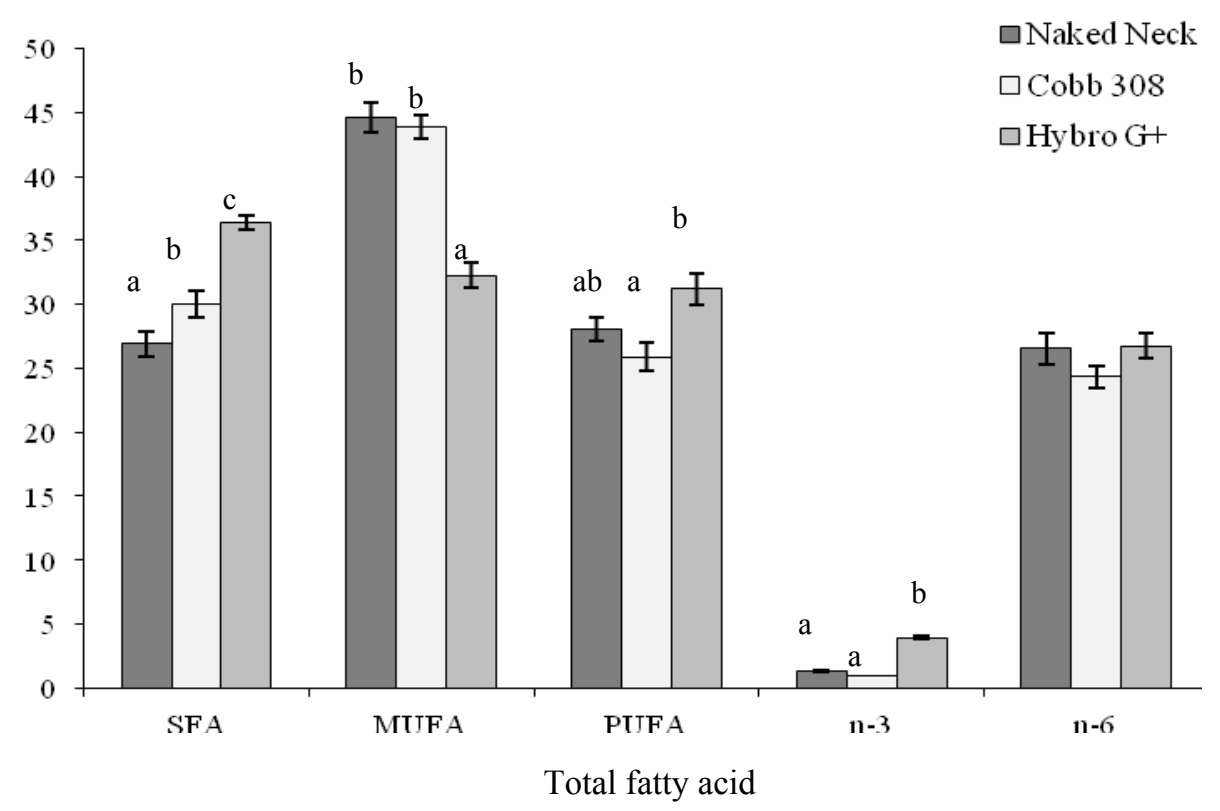

Figure 1. Differences in total fatty acid composition in breast (A) and thigh (B) meat of three chicken genotype

Each bar represents the mean \pm standard deviation;

Means within bars bearing different letters $(a, b, c)$ are significantly different at $p \leq 0.05$.

Pastures are a good source of n-3 fatty acids (Ponte et al., 2008) and consumer interest in specialty poultry products derived from free-range production systems is accompanied by a greater level of $n-3$ PUFA in this products. PUFA consumption reduces the risk of cardio-vascular disease (Temple, 1996) and inhibits the growth of mammary and prostate gland tumours (Pandalai et al., 1996). Significant variations were observed for polyunsaturated fatty acids (PUFA) in breast (Fig 1A), they were higher $(\mathrm{p} \leq 0.05)$ in Cobb 308 than in the other groups. Thigh PUFA (Fig. 1B) also differed significantly among the groups: Hybro $\mathrm{G}+$ showed higher $(\mathrm{p} \leq 0.05)$ values than Naked Neck and Cobb 308. The PUFA and total n-6 fatty acids had also opposite trends in breast and thigh of analysed chicken breeds (Fig 1). Cobb 308 breed had significantly higher $(\mathrm{p} \leq 0.05)$ content of PUFA and total n- 6 in breast meat, while in thigh meat it had the lowest values of PUFA and total n-3 fatty acids. Results of this experiment are inconsistent with the statement of Jaturasitha et al. (2008) who found that the meat of the Thai chickens (a native chicken breed) had higher proportions of n-3 fatty acids compared with Bresse and Rhode Island Red breeds (a commercial broiler breeds). 


\section{Conclusion}

Free ranged Naked Neck chickens have been shown to have significant different fatty acid composition compared with broiler chikens reared in conventional system. Breast meat from Naked Neck chickens had more SFA and less PUFA, but thigh meat had lower SFA and higher MUFA content compared with meat from comercial broilers. Total $n-6$ fatty acids content was lower in breast meat of Naked Neck chickens compared with Cobb 308 and total n-3 fatty acids were lower in thigh meat of Naked Neck breed compared with thigh meat from Hybro $\mathrm{G}^{+}$chikens. The results indicate that the genotypes used showed different abilities to incorporate fatty acids and a possible interaction between strain and environment may exist on absorption and utilization of dietary components.

\section{Acknowledgments}

Research was financed by the Ministry of Education, Science and Technological Development, Republic of Serbia, project TR-31033.

\section{Razlike u masno kiselinskom sastavu mesa između gološijana i dva komercijalna hibrida pilića}

\section{Z. Pavlovski, Z. Škrbić, N. Stanišić, S. Lilić, B. Hengl, M. Lukić, V. Petričević}

Cilj istraživanja je bio da se utvrdi razlika u masnokiselinskom sastavu mesa gološijana gajenih u slobodnom sistemu i dva komercijalna brojlerska hibrida (Cobb 308 i Hybro $\mathrm{G}^{+}$gajenih u konvencionalnom proizvodnom sistemu. $\mathrm{U}$ ogledu je bilo po 100 pilića po grupi. Tov u konvencionalnom sistemu je trajao 42 dana, a u slobodnom sistemu 84 dana. Meso grudi gološijana sadržalo je statistički više 16:0 u odnosu na Cobb $308(\mathrm{p} \leq 0.05)$, dok je meso karabataka hibrida Hybro $\mathrm{G}^{+}$ imalo veći sadržaj 16:0 masnih kiselina. Sadržaj masnih kiselina u mesu grudi između hibrida je bio različit za 14:0, 17:0, 18:0, 16:1, 18:1, 18:2, 20:2, 22:1 i 22:5 masne kiseline. Zaključno, može se reći da je u mesu gološijana gajenih u slobodnom sistemu utvrđen statistički značajno različit sadržaj masnih kiselina u poređenju sa brojlerima gajenih u konvencionalnom sistemu.

\section{References}

BOGOSAVLJEVIĆ BOŠKOVIĆ S., TOLIMIR N., PETROVIĆ M., DOSKOVIĆ V. (2003): Uticaj genotipa i pola na odabrane parametre i kvalitet mesa trupova brojlera. Biotechnology in Animal Husbandry, 5-6, 407-412. 
CASTELlini C., MUGNAI C., DAL BOSCO A. (2002): Effect of organic production system on broiler carcass and meat quality. Meat Science, 60, 219-225. JATURASITHA S., SRIKANCHAI T., KREUZER M., WICKE M. (2008): Differences in carcass and meat characteristics between chicken indigenous to Northern Thailand (Black-Boned and Thai Native) and imported extensive breeds (Bresse and Rhode Island Red). Poultry Science, 87,160-169.

MILIJAŠEVIĆ M., JANKOVIĆ S., RADIČEVIĆ T. (2009): Uticaj masnih kiselina u hrani na sastav masnih kiselina i količinu holesterola kod kalifornijske pastrmke (Oncorhynchus mykiss). Tehnologija mesa 50, 179-188.

MILOŠEVIĆ N., PERIĆ L., STRUGAR V., ŽIKIĆ D., PAVLOVSKI Z. (2005): Rearing of fattening chickens on free range and extensivily in chickens coop. Biotechnology in Animal Husbandry,5-6,125-136.

PANDALAI P.K., PILAT M.J., YAMAZAKI K., NAIK H., PIENTA K.J. (1996): The effects of omega-3 and omega- 6 fatty acids on in vitro prostate cancer growth. Anticancer Research, 16, 815-820.

PAVLOVSKI Z., ŠKRBIĆ Z., LUKIĆ M., VITOROVIĆ D., PETRIČEVIĆ V. (2009a): Nacked neck - Atochthonous breed of chicken in Serbia: carcass characteristics. Biotechnology in Animal Husbandry,1-2,1-10.

PAVLOVSKI Z., ŠKRBIĆ Z., LUKIĆ M., VITOROVIĆ D., PETRIČEVIĆ V. (2009b): Nacked neck chicken of Serbian and foreign origin: Carcass characteristic. Biotecnhologa in Animal Husbandry, 5-6, 1023-1032.

PONTE P.I.P., ALVES S.P., BESSA R.J.B., FERREIRA L.M.A., GAMA L.T., BRAAS J.L.A., FONTES C.M.G.A., PRATES J.A.M. (2008): Influence of pasture intake on the fatty acid composition, and cholesterol, tocopherols, and tocotrienols content in meat from free-range broilers. Poultry Science, 87, 80-88.

SPIRIĆ A., TRBOVIĆ D., VRANIĆ D., ĐINOVIĆ J., PETRONIJEVIĆ R., TEMPLE N.J. (1996): Dietary fats and coronary heart disease. Biomedicine and Pharmacotherapy, 50, 261-268.

SRPS EN ISO 5509 (2007): Animal and vegetable fats and oils - Preparation of methyl esters of fatty acids.

ŠKRBIĆ Z., PAVLOVSKI Z., LUKIĆ M., KRNJAJA V., BIJELIĆ Z., TRENKOVSKI S. (2010): Tehnologija proizvodnje pilećeg mesa u sistemu gajenja sa ispustom. Biotechnology in Animal Husbandry,spec.issue, 67-81.

WATTANACHANT S., BENJAKUL S., LEDWARD D.A. (2004): Composition, color, and texture of Thai indigenous and broiler chicken muscles. Poultry Science, 83, 123-128. 